\title{
14 Accountability for covert action in the United States and the United Kingdom
}

\author{
Mitt Regan and Michele Poole
}

States sometimes decide to conduct activities against adversaries without acknowledging their involvement in them. The decision to engage in such covert action creates a fundamental tension between the need for a state to fulfil its national security responsibilities and the principle that citizens in a liberal democracy should be informed about actions taken in their name so they can hold government accountable them (Lester 2015). Both the United States (US) and the United Kingdom (UK) have engaged in covert action for quite some time (Daugherty 2004; Cormac 2018). This chapter examines how each manages this tension. It reveals that, even as they accept the importance of accountability, liberal democracies may define the concept differently and use different mechanisms to provide it.

\section{Definition of covert action}

\section{United States}

The National Security Act of $1947^{2}$ established the Central Intelligence Agency (CIA) and charged it with collection of foreign intelligence and the performance of "such other functions and duties related to intelligence affecting the national security as the National Security Council may from time to time direct". ${ }^{3}$ The latter function was the basis for the agency's involvement in covert action until such operations were explicitly authorized by statute in 1991 (Snider 2008, 140).

Congress codified the definition of covert action in the 1991 Intelligence Authorization Act. That defines covert action as "an activity or activities of the United States Government to influence political, economic, or military conditions abroad, where it is intended that the role of the United States Government will not be apparent or acknowledged publicly". ${ }^{4}$ The statute provides that covert action does not include intelligence collection, and traditional diplomatic, military and law enforcement activities.

This definition distinguishes covert action from clandestine activities, which often are carried out by military units, especially Special Operations Forces. The distinction between intelligence collection and covert action ostensibly is that the

DOI: $10.4324 / 9781003164197-20$ 
former involves passive information gathering, while the latter involves operations designed to affect the environment. The line is not a sharp one, however. Covert action can generate considerable intelligence even if that is not its primary goal and such operations obviously rely on accurate intelligence in order to be effective.

\section{United Kingdom}

Unlike the US, the UK has no statutory definition of covert action. Military doctrine describes covert action as operations "planned and executed as to conceal the identity of, or permit plausible denial by, the sponsor" (Cormac 2018, 5). A recent report by the Intelligence and Security Committee of Parliament, a body discussed in more detail in the following, distinguishes between intelligence "coverage" and "effects", with covert action falling within the latter category. As the report describes,

Intelligence coverage is the collection of information (or acquisition of information from allied intelligence services) by the Agencies and Defence Intelligence. Intelligence effects describe the Agencies' and Defence Intelligence's engagement in activities that have real-life outcomes.

(Intelligence and Security Committee of Parliament 2020, 26)

The Secret Intelligence Services or MI6 has described its work as including "using covert contacts overseas to shape developments and exploit opportunities in the UK's interest" (Cormac 2018, 5) and leaked documents indicate that the Government Communications Headquarters (GCHQ), which has primary responsibility for signals intelligence, has its own " online covert action' programme" (Cormac 2014).

Unlike the US, the UK does not formally or publicly distinguish between covert and clandestine action, nor between covert action and intelligence gathering. In contrast to the CIA, MI6 does not have its own paramilitary assets and so must work closely with UK Special Forces (UKSF). Indeed, UKSF are regarded as an asset that may be utilized by any agency when necessary. UK covert action thus consists of activities the US would consider clandestine military operations not subject to its covert action statute. Similarly, UK agencies do not have the resources that would enable them to clearly distinguish intelligence collection and covert action. This contrasts with the CIA, which has separate offices responsible for intelligence and operations.

The absence of sharp distinctions also is consistent with the UK's emphasis on secrecy as essential to operational effectiveness. Both law and custom reflect a UK tradition in which government is provided considerable deference and flexibility in matters of national security (Cormac 2018, 5). As the discussion below describes, a broad conception of covert action creates challenges for any effort by Parliament to exercise effective oversight of this activity. 


\section{Responsibility for covert action}

\section{United States}

Executive Order 12,333 provides that "[n]o agency except the Central Intelligence Agency . . . may conduct any covert action activity unless the President determines that another agency is more likely to achieve a particular objective". The Directorate of Operations in the CIA oversees the Special Activities Center (SAC), which is responsible for conducting covert action. Within the SAC are the Special Operations Group (SAC/SOG), responsible for covert paramilitary operations, and the Political Action Group (SAC/PAG), responsible for covert political action, and psychological, economic and cyber operations (Harper 2015). SAC/ SOG is largely comprised of former and current US Special Operations Forces. When active duty service members conduct covert action, they typically do so under the legal authority of the CIA Director, such as occurred in the operation that resulted in the death of Osama bin Laden.

The National Security Agency (NSA) was established by President Truman in 1952 to provide unified control over communications intelligence activities (Homeland Security Digital Library 1952). The mission of the NSA has expanded beyond the collection of communications intelligence to include offensive cyber operations, which almost certainly include covert action. In 2010 US Cyber Command (CYBERCOM) was created under the command of the then director of the National Security Agency. Its mission is to "direct, synchronize, and coordinate cyberspace planning and operations to defend and advance national interests in collaboration with domestic and international partners".

A component of the military available to assist in covert action is US Special Operations Forces (SOF). US Special Operations Command (SOCOM) oversees SOF from the Army, Air Force, Navy and Marines, as well as a Joint Special Operations Command (JSOC), which is itself comprised of units from each of the services. SOCOM reports directly to the Secretary of Defense and the President. JSOC's primary mission is to train and conduct special operations missions in support of traditional military operations, but elements of the force are sometimes placed under the legal authority of the CIA for the conduct of covert operations.

The National Security Council (NSC) serves as an important mechanism to coordinate covert action, based on its responsibility to "advise the President with respect to the integration of domestic, foreign, and military policies relating to the national security". The National Security Act of 1947 placed the CIA under the National Security Council and the NSC works to coordinate covert action across relevant government agencies.

Finally, the exception for traditional military activities under the covert action statute means that the military may conduct some covert operations that are not subject to the requirements of the statute. Recent legislation established that, in addition to kinetic activity, this exception includes cyber and information operations. As the discussion below describes, such activities are subject to separate requirements that resemble those in the covert action statute. 


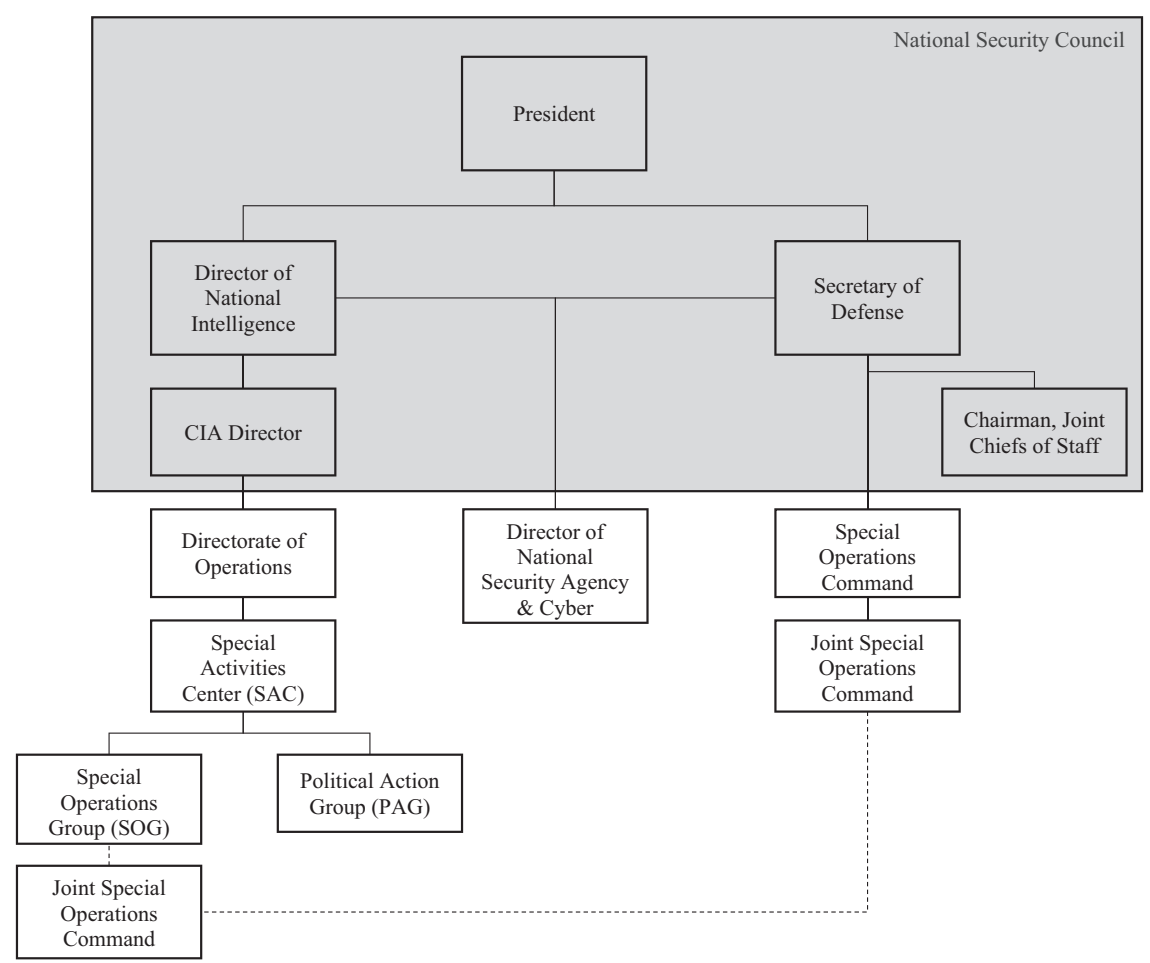

Figure 14.1 US components with responsibility for covert action.

Figure 14.1 depicts the elements of the US government with responsibility for covert action operations.

\section{United Kingdom}

As far as is possible to discern, UK covert action is not solely, or even mainly, the preserve of one agency. The Secret Intelligence Service (MI6) and/or the Government Communications Headquarters (GCHQ), which is responsible for signals intelligence, are the most likely agencies to undertake it. The Security Service (MI5) theoretically could do so but this is much less likely given its domestic remit. Covert action also has allegedly been conducted by other entities such as the Research, Information and Communications Unit (RICU), the UK's specialist strategic communications unit that conducts counter-jihadist propaganda. Covert action by the UK thus is decentralized, dependent on the resources and needs of various agencies with respect to particular operations. Equally or even more important are the needs of various offices such as the Foreign and Commonwealth Office (FCO). Traditionally, the FCO has had the responsibility of officially 
signing off on covert action, but it is unclear how much it has been involved in initiating it.

The lack of a single agency with primary responsibility for covert action not only reflects practical considerations, but is also consistent with the UK tradition of providing minimal information about the responsibilities of its intelligence and security agencies. For example, in 1924, 15 years after MI5 was created, the British Foreign Secretary declared during Parliamentary debate,

It is the essence of a Secret Service that it must be secret, and if you once begin disclosure it is perfectly obvious to me as to Hon. Members opposite that there is no longer any Secret Service and that you must do without it.

(Andrew 2009, 753)

This philosophy persisted until late in the twentieth century and did not change until judicial decisions and scandal prompted reforms. In 1987, in a case involving Sweden, the European Court of Human Rights ruled that privacy provisions of the European Convention on Human Rights required that infringement on human rights "must have some basis in domestic law ... [and] the law in question must be accessible to the individual concerned and its consequences for him must also be foreseeable" (Andrew 2009, 758). The Security Service Act of 1989 then explicitly incorporated MI5 into British law as a statutory domestic security service. Its most significant responsibility is

the protection of national security, and, in particular, its protection against threats from espionage, terrorism and sabotage, from the activities of foreign powers and from actions intended to overthrow or undermine parliamentary democracy by political, industrial or violent means.

The impetus for comparable legislation regarding MI6 and GCHQ was the 1992 trial of three businessmen prosecuted in the Matrix Churchill scandal for illegal arms sales to Iraq. The trial revealed that MI6 had been aware of and advised the defendants on the sales and had been using the intelligence provided by one of them. The trial collapsed as a result and the Intelligence Services Act (ISA) of 1994 was passed in the midst of the three-year judiciary inquiry of the scandal (Gill 2007, 20). ISA formally established the Secret Intelligence Service (SIS), or MI6, as the UK foreign intelligence service and the GCHQ as its signals intelligence agency.

Two elements of the UK's uniformed military services conduct or support covert action - Defence Intelligence (DI) and UK Special Forces (UKSF). DI is a component of the Ministry of Defence (MoD) and conducts all-source intelligence analysis "providing intelligence products and advice to policy, deployment and research decisions". It provides support to planning and execution of covert action operations and benefits from intelligence collected during them.

Since 1987 UK Special Forces have existed as a separate directorate in the Ministry of Defence comprised of components from the British Army and Royal 
Navy, later expanded to include the Royal Air Force. UK Special Forces conducts "short notice high risk operations in support of UK interests" under Joint Forces Command (Joint Forces Command n.d.). They are funded through the Ministry of Defence, but are considered a national asset for covert action, with a subset of UKSF serving the Secret Intelligence Service (Cormac 2018, 9). UK Special Forces is the last remaining government organization on which the government refuses to comment. There is an absolute exemption for UKSF under the Freedom of Information Act 2000 and it is government policy "not to comment, and to dissuade others from commenting or speculating, about the operational activities of Special Forces because of the security implications" (Directorate of Special Forces n.d.).

Finally, in 2010, Prime Minister David Cameron created the National Security Council (NSC) as a Cabinet committee to coordinate the government's work on national security, including the management of covert action (Cormac, Goodman, and Holman 2016, 15). The NSC is chaired by the Prime Minister, includes ten other Ministerial members, and can draw upon other senior government officials like the Chief of the SIS or Director of GCHQ, if their presence is relevant to the issues before the council (Devanny and Harris 2014, 24). It is supported by a secretariat of approximately 200 officials led by a National Security Adviser (NSA) (Devanny and Harris 2014, 25, 27). Operations that require inter-department cooperation are likely to be reviewed by the NSC. Certain MI6 operations involving the FCO, however, are more likely to be reviewed by the Foreign Secretary, who will be the dominant cabinet figure overseeing such operations.

\section{Regulation and oversight of covert action}

\section{United States}

US conduct of covert action is subject to a detailed set of regulatory requirements that are designed to further both rigorous internal Executive branch review and informed oversight by Congress. From the creation of the CIA in 1947 through the mid-1970s, covert action was relatively unregulated and not explicitly subject to Congressional oversight. This changed as a result of hearings in the House and Senate in 1975. These produced evidence suggesting some CIA connection to events that resulted in the attempted or successful assassination of foreign leaders (Weiner 2008). They also revealed extensive surveillance of persons within the United States based on political beliefs and perceived national security risks (Senate Select Committee to Study Governmental Operations with Respect to Intelligence Activities 1976; 1975). The result was a series of reforms beginning in the mid-1970s that culminated in the Intelligence Authorization Act of 1991, which set forth the current statutory regime of regulation.

The main requirements of the US covert action statute are that the president must make a written finding in support of a covert action and must notify the Congressional intelligence committees before the action begins. The finding must reflect the president's determination that "such an action is necessary to support 
identifiable foreign policy objectives of the United States and is important to the national security of the United States". The President "may not authorize any action that would violate the Constitution or any statute of the United States". ${ }^{5}$ While notification may occur after a programme has been initiated, informal practice generally has been that it will occur within 48 hours. The statute provides:

If the President determines that it is essential to limit access to the finding to meet extraordinary circumstances affecting vital interests of the United States, the finding may be reported to the chairmen and ranking minority members of the congressional intelligence committees, the Speaker and minority leader of the House of Representatives, the majority and minority leaders of the Senate, and such other member or members of the congressional leadership as may be included by the President [this is known as the "Gang of Eight"].

If the president elects to notify only the Gang of Eight, the intelligence committees of the House and Senate must be informed of this decision.

The provision that prohibits authorization of covert action in violation of the US Constitution or any US statute has been construed by the Executive Branch to permit the president to authorize covert action in violation of any US international law obligations that have not been incorporated into US law. Most notably, this would include the customary international law prohibition on intervention into the sovereign functions of another state.

The notification obligation of the president applies to covert action programmes, which may consist of several individual operations. The president must inform Congress of each programme, but is not required to provide notification prior to each separate operation. In addition, the president must notify Congress of any significant change in a previously approved covert action programme ${ }^{6}$ Notification for these purposes generally takes the form of a Memorandum of Notification (MON). One expert on covert action suggests the MON requirement is important because a presidential finding may be in broad language. Thus, "where and how the president, his policymakers, and his lawyers define these threshold terms can be critical in determining what measure of internal and then external review [that] specific initiatives or operational proposals receive, if any" (Baker 2010). The statute imposes additional requirements on relevant agencies to keep congressional intelligence committees fully informed of covert action activities, "including significant failures" (Baker 2010).

The requirement of a written Presidential finding has resulted in the creation of procedures within the Executive branch for review and approval of covert action. Typically, the president sends the CIA a request for a covert action finding. That agency engages in an extensive analysis, which includes consultation with its station chiefs in all countries that may be affected by a programme. Review occurs at several levels of the agency, eventually resulting in a proposed finding that is sent to the CIA Director. One report suggests that there is some contact between the CIA and Congress even in advance of the submission of a proposed presidential finding: 
According to a CIA officer with paramilitary experience, once the CIA begins to plan a covert action and define the terms of the finding, they begin to "socialize" the idea with the [House and Senate Intelligence Committee] chairmen. This opens up a dialogue with Congress, albeit limited in its scope, which affords an opportunity to address any initial questions that arise.

(Rudd 2015, 10)

When the director transmits the finding to the White House, it goes to an interagency working group for covert action that involves representatives from the State Department, the Defense Department, the Joint Chiefs of Staff, Office of Management and Budget and the Justice Department. After review by this group, it goes to the National Security Council, which submits to the president a recommendation, including all dissents, on each proposed covert action. Once the NSC presents a proposed finding to the president for his or her approval, the president notifies the Congressional intelligence committees. A separate document describes policy objectives, the plan of action, an assessment of the risks involved and a description of the resources that will be required.

The exclusion of traditional military operations from the statutory definition of covert action means that any covert military activities are not subject to the procedures set forth in the statute. There are, however, regulatory provisions that resemble those in the statute for specific types of military operations. The Secretary of Defense is required to notify the Congressional Armed Services committees no less than 48 hours before initiation of a "sensitive military operation", which is defined as a lethal or capture operation against a specific person or persons outside certain conflict theatres. This requirement serves to furnish Congress with timely information about unacknowledged SOF operations. In addition, the Secretary of Defense must notify the Armed Services Committees no less than 15 days before using funds authorized for payment to foreign and local groups and must file an annual report summarizing SOF counter-terrorism operations assisted by groups receiving these funds.

Any "clandestine" military cyber operation that is covert must be authorized by the president or the Secretary of Defense. ${ }^{7}$ This requirement is similar to the requirement of a presidential finding under the covert action statute, although it is unclear the extent to which it involves consultation with multiple agencies as occurs with a covert action finding. The Secretary of Defense must notify the Armed Services Committees within 48 hours of any cyber operations outside theatres of hostilities. Legislation also exempts from the covert action statute military information operations "short of hostilities and in areas outside of areas of active hostilities". The Secretary of Defense must report to the Armed Services Committees any "significant" such operations conducted by the Department in the preceding quarter. ${ }^{8}$

\section{United Kingdom}

Rory Cormac suggests that there may be at least two mechanisms in the UK for executive oversight of covert action. One is the Foreign Office, which by statute 
must approve any such operation (Cormac 2018, 13). The other is the National Security Council (NSC) described earlier. Cormac notes that:

[t]here is some suggestion that the NSC is now the primary forum for covert action tasking and scrutiny. This may be because it brings together the heads of the agencies and the military with the PM and key cabinet members like the Foreign and Defence Secretaries on a weekly basis. The NSC and Foreign Office processes may work together or could be used interchangeably depending on operational needs.

With respect to oversight by Parliament, the 1994 Intelligence Services Act created the first parliamentary oversight mechanism, the Intelligence and Security Committee (ISC). The Act described the Committee's mandate as "to examine the expenditure, administration, and policy" of MI5, MI6 and GCHQ. The Committee was granted access to classified material. There were concerns, however, that it was insufficiently independent because, although comprised of members of Parliament, it was not a parliamentary committee but a statutory committee appointed by and reporting to the Prime Minister.

The Justice and Security Act of 2013 and the resulting Memorandum of Understanding Agreed Between the Prime Minister and the Intelligence and Security Committee of Parliament substantially changed the structure, authority and mandate of the ISC (Intelligence and Security Committee of Parliament 2014, 11). Members are now nominated by the Prime Minister and appointed by a vote of their relevant House of Parliament (Intelligence and Security Committee of Parliament 2014, 11). The ISC now has its own staff - the ISC Secretariat - although members are seconded from the Cabinet Office. The ISC reports its findings to the Prime Minister, who then reports them to Parliament with redactions of sensitive information. Only the Secretary of State may withhold information from the ISC, on the ground that "it is sensitive and should not be disclosed to the ISC in the interests of national security". Information can be withheld from other parliamentary committees if the Secretary of State thinks "it proper not to do so" and is "not limited to national security" grounds (Dawson 2020, 8). Notwithstanding this, the Prime Minister retains significant control over the process, as reflected, for instance, in delays in releasing ISC reports and in reconstituting the committee after an election.

The ISC's oversight authority was extended beyond the three major intelligence agencies to include the intelligence and security work of a number of other offices, including the Chief of Defence Intelligence (DI) and offensive cyber activities in the Ministry of Defence; the Joint Intelligence Organisation, National Security Secretariat and Assessments Staff in the Cabinet Office; and the Office for Security and Counter-Terrorism (OSCT) in the Home Office (Intelligence and Security Committee of Parliament 2014, 12).

The Committee's role with respect to covert action is entirely retrospective that is, it has no role in oversight of operations before or while they were taking place. This reflects the preference of the ISC Chair, Malcolm Rifkind, at the time 
that the committee was created. "There is no benefit, and a lot of risk", Rifkind said, "in having been briefed in advance of a secret operation unless you can influence whether it goes ahead. Otherwise, you have responsibility without power, which is even worse than power without responsibility" (Rifkind 2016, 428).

In contrast to the US, one organization integral to covert action that remains free of parliamentary oversight is UK Special Forces (UKSF). The ISC is the only committee that has members cleared to review classified material, but it has no mandate to provide oversight of UKSF. The Defence and Foreign Affairs Committees that oversee the organizations to which UKSF are assigned have no security clearance. A member of the Foreign Affairs Select Committee raised this issue in November 2017, asking if the MoD would "undertake a review of access to information on Special Forces by Parliament to enable effective scrutiny", and he was told, "Given the sensitivity of their activities, oversight of Special Forces is exercised through the Prime Minister and Defence Ministers. We have no plans to change the current arrangements". The year before, the Defence Ministry representative refused to answer any of an MPs questions related to the UK Special Forces, repeating seven times to seven separate questions, "I cannot comment on specific questions about personnel, equipment, discussions or activities in relation to these units" (Walpole and Karlshoej-Pedersen 2018, 4-6).

\section{Comparative analysis}

As the preceding discussion makes clear, there are not only some similarities but also some important differences in how the US and UK seek to ensure accountability for covert action. This section focuses on the main differences and their potential significance.

\section{Definition of covert action and designation of lead agency}

The US defines covert action in a statute that establishes requirements for engaging in such operations. That definition excludes some activities that may be conducted covertly, such as military activities. This results in different procedures and oversight mechanisms for activities formally defined as covert action and military covert operations that are not. Both require some form of notification of Congress, although military information operations need only be reported quarterly. Statutory covert action requires a presidential finding, while military covert action does not, although the Secretary of Defense presumably has a prominent role in the latter.

The designation of the CIA as primarily responsible for statutory covert action means that Congressional Intelligence committees exercise oversight over the CIA, while Armed Services committees do so over military covert operations. The US thus effectively has a parallel system of covert action accountability for CIA and military operations. Other agencies have interests in such operations and have opportunities to weigh in, most notably for CIA operations. It is clear, however, which agency has primary responsibility in each system. 
By contrast, various UK agencies have definitions of covert action, but there is no statutory definition. Nor is any entity designated as the lead agency for such operations. The philosophy, perhaps shaped also by resource constraints, is that any given agency may have an interest in a particular operation and may have assets that are especially suitable for it. Covert action thus involves "[m] ultiple actors, often with diverging visions and goals", which "require greater coordination" (Cormac, Goodman, and Holman 2016, 17). This creates the potential for counterproductive competition among agencies, although in practice MI6 generally takes the lead, with GCHQ also sometimes doing so. The NSC has the potential to coordinate operations, but it has broad responsibilities and less experience with covert action than its US counterpart.

This decentralized approach also may produce gaps in Parliamentary oversight. Unlike the US, there is no committee charged with covert action oversight. The ISC oversees the intelligence agencies, but since covert action is a means of executing foreign policy, the Foreign Affairs Committee (FAC) arguably has an interest in overseeing it. Oversight of covert action formally comes within the ISC remit, but until recently the committee had no authority to review operations in advance. With limited exceptions, it tends to focus on broad policy and strategic issues. In addition, since covert action may involve the military, the House of Commons Defence Committee (HCDC) could be involved. Because the line between covert action and intelligence can be indistinct, however, neither FAC nor HCDC are entirely natural oversight forums for covert action. Furthermore, the ISC is the sole committee whose members may view classified information, which as a practical matter prevents FAC and HCDC from conducting effective oversight.

\section{Notification of the legislature}

A significant difference between the US and UK covert action process is that the former requires advance notification of Congress while the latter does not. Parliament therefore is limited to retrospective review of operations. This reflects the historical preference of ISC leadership, which believes that advance notice would result in the committee sharing responsibility for operations without any authority to influence them.

Based on the US experience, it is not clear whether this concern is necessarily warranted. Congress has no statutory authority to approve or disapprove of any covert action, but it does have the potential to exercise influence (Cumming $2010,5)$. The preparation of a finding by the CIA involves informal consultation with Congress, and formal notification historically has provided an opportunity for Congress to express its views on the practical, legal and political risks of proposed operations. Senator John Warner, who served on the Senate Intelligence committee, has written,

Congressional oversight has uncovered instances when covert actions were not properly reviewed or assessed within the executive branch. It has also 
contributed to the reconsideration of activities or the particular details of their execution. On occasion, it has blocked some and terminated others.

(Warner 1989, 107)

The ISC thus may be forgoing an informal opportunity to shape covert action by declining to seek advance notification.

\section{Oversight of special operations forces}

Another major difference between the US and UK is that the former provides for Congressional oversight of SOF while the latter does not. US military covert action generally will be carried out by SOF. Military covert action is not subject to the requirements of the covert action statute, but the requirement that the Department of Defense notify the Armed Services committees of various kinetic, cyber and information operations provides a mechanism for oversight of military covert action in general and SOF in particular. By contrast, the UK has no statute authorizing SOF and declines to comment on their operations or existence. ISC members have security clearances, but that committee oversees the intelligence agencies. The HCDC may informally oversee SOF, but its members do not have access to classified information. The Ministry of Defence presumably engages in oversight, but of course is formally a member of the executive branch.

\section{Washington and Westminster systems}

Oversight of covert action by the legislature in the US and UK is of course affected by the differences in those countries' systems of government. The US sharply differentiates between the executive and Congress, with members of Congress prohibited from serving simultaneously in the executive branch. By contrast, the executive is a component of Parliament in the UK. The authority of the executive to govern in the UK is based on its dominance of Parliament, with the Cabinet composed mainly of leading members of the House of Commons. Thus, the chair of the UK ISC has been from the same party as the Prime Minister in all but four of the 25 years that committee has been in existence. By contrast, over that same period the chair of the House and Senate intelligence committees has been from the same party as the president only $32 \%$ and $50 \%$ of the time. More generally, since 1945 the House has been controlled by the opposing party $68 \%$ of the time and the Senate $50 \%$ of the time.

The timing of elections in the two systems also differs. The US has elections every two years for every House member and one-third of Senate members. Parliament may not exceed five years between elections, and the timing of those elections is usually determined by the Government, with 30 days' notice between announcement and the day of election (Peterson 2005). The work of the ISC may not carry over from one Parliament to the next and it and other committees must 
be re-established after elections. After general elections, the ISC has been one of the last committees reconstituted.

[I]n the three years from 2015 to the end of 2017, Britain was without a legislative intelligence oversight body for almost 12 months. There were four terrorist attacks in the UK in the period in which the committee was in desuetude in 2017.

The situation has been described as "deeply unsatisfactory" (Defty 2019, 9).

Because US congressional elections occur at a regular interval, the outgoing Congress continues to sit during most of the period between election day and the swearing in of the new Congress. Committee assignments for the new Congress are decided during this time, which provides for continuity of oversight.

The lesser role of legislative oversight in providing accountability for covert action in the UK is reflected in the fact that although recent reforms to the ISC increased its authority to request information from the executive, the executive can refuse to provide such information with few repercussions. An example was a recent ISC inquiry into the decision-making behind drone strikes in Syria that resulted in the deaths of three UK citizens. The ISC announced that it planned to investigate the intelligence basis for the strikes. The Prime Minister responded that the strike was part of ongoing operations and therefore was beyond the scope of the Committee's remit. He noted, however, the significant public interest in assessing the threat that one of the victims posed and asked the Committee to conduct an investigation confined to this question (Intelligence and Security Committee of Parliament 2017, 2).

The ISC conducted oral interviews and received the written intelligence assessments and reports that formed the basis for the threat determination. It requested information on targeting procedures, collateral damage estimates and other matters that were used in the decision-making. The executive refused on the ground that these were outside the scope of the investigation. ISC disagreed with that assessment and noted in its report that the unavailability of this information hindered its ability to provide a full review of the operation.

Finally, oversight of covert action by the US and UK also reflects cultural differences. The UK is more comfortable with secrecy by the executive and with unwritten policy and procedures, perhaps reflecting more trust in the government than exists in the US. The extensive formal regulatory provisions that govern covert action in the US reflected a tradition of greater distrust and emerged because of congressional hearings that revealed considerable questionable covert operations undertaken by the CIA from the end of World War II until the early 1970s.

\section{Executive branch process}

To the extent that there are limits on the ability of Congress or Parliament to oversee covert action, robust internal executive branch deliberation can further accountability by ensuring that decisions are informed by multiple perspectives that take into account a wide range of considerations. Crucial to this process is reason-giving, the 
requirement that individuals be able to justify their positions to others. This requirement is especially important in settings in which many reasons cannot be publicly articulated, such as in the national security setting. In these situations, what Ashley Deeks calls secret reason-giving "improves the overall quality and effectiveness of government decision-making and operations, constrains the decision-maker, and strengthens the decision-maker's legitimacy" (Deeks 2020, 616).

The requirement of a Presidential finding under the US covert action statute appears to foster this process within the executive branch. Extensive review of a proposed finding occurs within the CIA, sometimes involving informal consultation with Congress. The proposal is then sent to a working group comprised of members of several agencies, after which it is reviewed by the NSC before submission to the President. By the time a finding reaches the President, it has been reviewed by multiple individuals and organizations with varying expertise, perspectives and interests.

In the UK, "there needs to be particular emphasis on robust internal deliberation within the executive, since the onus of ensuring meaningful covert action oversight rests almost entirely" on this mechanism (Djabatey 2018). It is possible that the process is as comparably as wide-ranging as in the US, but there is no public information about it. The Foreign Office historically has been required to authorize covert action and may serve to coordinate consideration of proposed operations. Its influence at least in theory has meant that British covert action is tied to foreign policy and has given British covert action a generally cautious character (Djabatey 2018). On the other hand, the NSC now may have assumed the primary coordinating role, since it brings together the heads of the agencies and the military with the PM and key cabinet members on a weekly basis. Interagency consultation in the UK does not appear to be as formalized as it is in the US, but the NSC has the potential to foster this practice. In addition, interagency bodies that allegedly engage in forms of covert action exist, such as the RICU. The NSC and Foreign Office processes may work together, or could be used interchangeably depending on operational needs.

In any event, more transparency about the UK process could serve to enhance a sense of accountability for covert action. With respect to the US targeted killing programme, for instance, disclosure of the process for selecting targets, albeit as a result of litigation, provided the public with a greater understanding of the parties involved in the process, the criteria they apply and the evidence required at each step of the deliberations. Such disclosure also can provide at least general standards by which the public can assess the programme. Something comparable for UK covert action could both provide reassurance of rigorous deliberation and encourage officials to engage in it.

\section{Conclusion}

US covert action is explicitly authorized and regulated by publicly available standards, in contrast with the UK's reluctance to formalize or disclose the process for conducting such activity. This likely reflects much greater reliance by the US 
on covert action than the UK, the sharper separation of powers in the US system, and greater resources that allow the US to differentiate among intelligence, covert action and unacknowledged military operations. While the US system does not automatically ensure full accountability for covert action, it does at least provide some public standards against which it can be evaluated.

Other factors that contribute to the differences between the two systems may be the UK's history of greater reliance on and confidence in elites and a preference to avoid clear lines of demarcation in order to preserve freedom of action. Nonetheless, there is growing public demand for government transparency and for accountability even for secret operations. With a weaker system of legislative oversight than in the US, the UK may need to disclose more information about executive branch decision-making on covert action to meet this demand.

\section{Notes}

1 We are grateful for comments on a draft of this chapter by Rory Cormac.

2 National Security Act of 1947, Pub. L. No. 80-253, 80th Cong. 1st sess (1947).

3 National Security Act of 1947, Pub. L. No. 80-253, 80th Cong. 1st sess, § 102(d)(5) (1947).

450 USC $\S 3093(\mathrm{e})$.

550 USC $\S 3093(a)$.

650 USC $\S 3093(\mathrm{~d})$.

7 Legislation uses the term "clandestine" to emphasize that such operations are not subject to the covert action statute, but the definition of clandestine includes unacknowledged operations.

8 As with military cyber operations, clandestine information operations include those that are unacknowledged.

\section{References}

Andrew, Christopher. 2009. The Defence of the Realm: The Authorized History of Mi5. London; New York: Allen Lane.

Baker, James E. 2010. "Covert Action: United States Law in Substance, Process, and Practice". In The Oxford Handbook of National Security Intelligence, edited by Loch K. Johnson. New York: Oxford University Press. https://doi.org/10.1093/oxfor $\mathrm{dhb} / 9780195375886.001 .0001$.

Cormac, Rory. 2014. “GCHQ's Cyber Offensive: Online Covert Action”. Ballots \& Bullets School of Politics \& International Relations, University of Nottingham, February 13. https://nottspolitics.org/2014/02/13/gchqs-cyber-offensive-online-covert-action/.

- 2018. Disrupt and Deny: Spies, Special Forces, and the Secret Pursuit of British Foreign Policy. New York; Oxford: Oxford University Press.

Cormac, Rory, Michael S. Goodman, and Tom Holman. 2016. "A Modern-Day Requirement for Co-Ordinated Covert Action". The RUSI Journal 161 (2): 14-21. https://doi. org/10.1080/03071847.2016.1174478.

Cumming, Alfred. 2010. Sensitive Covert Action Notifications: Oversight Options for Congress. Washington, DC: Congressional Research Service. https://apps.dtic.mil/dtic/ tr/fulltext/u2/a514137.pdf.

Daugherty, William. 2004. Executive Secrets: Covert Action and the Presidency. Lexington: University Press of Kentucky. 
Dawson, Joanna. 2020. The Intelligence and Security Committee Briefing Paper No. 02178. House of Commons Library. https:/commonslibrary.parliament.uk/research-briefings/ sn02178/.

Deeks, Ashley S. 2020. “Secret Reason-Giving”. The Yale Law Journal 129 (3): 612-89.

Defty, Andrew. 2019. "Coming in from the Cold: Bringing the Intelligence and Security Committee into Parliament”. Intelligence and National Security 34 (1): 22-37. https:// doi.org/10.1080/02684527.2018.1513441.

Devanny, Joe, and Josh Harris. 2014. The National Security Council National Security at the Centre of Government. Institute for Government. www.instituteforgovernment.org. uk/publications/national-security-council.

Directorate of Special Forces. n.d. "UK Special Forces". Accessed December 1, 2020. www.gov.uk/government/groups/directorate-of-special-forces.

Djabatey, Edwin. 2018. "On the Difficulties of Examining British Oversight of Covert Action (Unpublished Manuscript)".

Gill, Peter. 2007. "Evaluating Intelligence Oversight Committees: The UK Intelligence and Security Committee and the 'War on Terror'". Intelligence and National Security 22 (1): 14-37. https://doi.org/10.1080/02684520701200756.

Harper, Lauren. 2015. "First Complete Look at the CIA's National Clandestine Service Org Chart". Unredacted: The National Security Archive Blog (blog). October, 27. https:// unredacted.com/2015/10/27/first-complete-look-at-the-cias-national-clandestine-service-org-chart/.

Homeland Security Digital Library. 1952. "National Security Agency Established". Homeland Security Digital Library. www.hsdl.org/c/tl/national-security-agency-established/.

Intelligence and Security Committee of Parliament. 2014. Annual Report 2013-2014. London: HMSO. http://isc.independent.gov.uk/files/2013-2014_ISC_AR.pdf.

2017. UK Lethal Drone Strikes in Syria. London: HMSO. http://isc.independent. gov.uk/files/20170426_UK_Lethal_Drone_Strikes_in_Syria_Report.pdf.

_. 2020. Russia. London: HMSO. https://docs.google.com/a/independent.gov.uk/ viewer?a=v\&pid=sites\&srcid=aW5kZXBlbmRlbnQuZ292LnVrfGlzY3xneDo1Y2Rh MGEyN2Y3NjM0OWF1.

Joint Forces Command. n.d. “About Us”. Accessed December 1, 2020. www.gov.uk/ government/organisations/joint-forces-command/about.

Lester, Genevieve. 2015. When Should State Secrets Stay Secret?: Accountability, Democratic Governance, and Intelligence. Cambridge: Cambridge University Press. https:// doi.org/10.1017/CBO9781107337015.

Peterson, Eric R. 2005. Parliament and Congress: A Brief Comparison of the British House of Commons and the U.S. House of Representatives. Washington, DC: Congressional Research Service. https://fas.org/sgp/crs/misc/RL32206.pdf.

Rifkind, Sir Malcolm. 2016. Power and Pragmatism: The Memoirs of Malcolm Rifkind. 1st edition. London: Biteback Publishing.

Rudd, Joshua. 2015. "Enhancing Congressional Oversight of DOD Clandestine Activities: A Case Study of SOF CT Paramilitary Operations". United States Army War College. https://duke.app.box.com/s/p6quvogzdsupnkon3rlx87rrejs1xt8x.

Senate Select Committee to Study Governmental Operations with Respect to Intelligence Activities. 1975. Alleged Assassination Plots Involving Foreign Leaders. Washington, DC: US Government Printing Office. www.intelligence.senate.gov/sites/default/files/94465.pdf.

- 1976. Intelligence Activities and the Rights of Americans Book II. Washington, DC: US Government Printing Office. www.intelligence.senate.gov/sites/default/ files/94755_II.pdf. 


\section{Mitt Regan and Michele Poole}

Snider, L. Britt. 2008. The Agency and the Hill: CIA's Relationship with Congress, 19462004. Washington, DC: Center for the Study of Intelligence.

Walpole, Liam, and Megan Karlshoej-Pedersen. 2018. Britain's Shadow Army: Policy Options for External Oversight of UK Special Forces. London: Oxford Research Group Remote Warfare Programme. www.oxfordresearchgroup.org.uk/Handlers/Download. ashx?IDMF=9bdb8bdd-2502-478f-9468-ac75af830d37.

Warner, John W. 1989. "Covert Action and Congressional Oversight”. Harvard International Review 11 (3): 106-9.

Weiner, Tim. 2008. Legacy of Ashes: The History of the CIA. Illustrated edition. New York: Anchor. 